\title{
Kemandirian Belajar Secara Daring Sebagai Prediktor Hasil Belajar Mahasiswa Pendidikan Matematika UIN Sunan Kalijaga
}

\author{
Riza Nur Fadila ${ }^{1}$, Tia Ainun Nadiroh ${ }^{2}$, Ria Juliana ${ }^{3}$, Primasari Zahrah Hafizhotu Zulfa ${ }^{4}$ Ibrahim $^{5}$ \\ 1, 2,3,4,5 Program Studi Pendidikan Matematika, Fakultas Ilmu Tarbiyah dan Keguruan, UIN Sunan Kalijaga Yogyakarta, \\ Jalan Laksda Adisucipto, Sleman, Daerah Istimewa Yogyakarta, Indonesia \\ rizanfadila48@gmail.com
}

\begin{abstract}
Online learning problems in collegs, such as the lack of material explanation by lecturers, cause students to be demanded to have more self regulated learning. There for self regulated learning is important achieving learning outcomes during online learning. The purpose of this study is to determine the prediction of student learning outcomes from self regulated learning during online learning and the correlation between self regulated learning and learning outcomes. This research is a survey research that uses a quantitative approach. The subjects were 67 active students of Mathematics Education at UIN Sunan Kalijaga even semester of the 2019/2020 academic year. The data collection instruments were self regulated learning questionnaire and database Study Result Card. Data analysis used descriptive statistical analysis and simple linear regression analysis. The results showed that self regulated learning could be used predictions of the learning outcomes of Mathematics Education Students at UIN Sunan Kalijaga and the higher self regulated learning, the higher the learning outcomes will be. This proves that online self regulated learning has an important role in student learning outcomes, so that students can increase their self regulated learning so that their learning outcomes can increase.
\end{abstract}

Keywords: Self Regulated Learning, Online, Student Learning Outcomes, Mathematics Education

\begin{abstract}
Abstrak
Permasalahan pembelajaran daring di perguruan tinggi seperti kurangnya penjelasan materi oleh dosen menyebabkan mahasiswa dituntut lebih memiliki kemandirian belajar. Oleh karena itu kemandirian belajar penting dalam mencapai hasil belajar selama pembelajaran daring. Tujuan penelitian ini yaitu mengetahui prediksi hasil belajar mahasiswa dari kemandirian belajar selama pembelajaran daring dan korelasi antara kemandirian belajar dengan hasil belajar selama pembelajaran daring. Penelitian ini merupakan penelitian survey yang menggunakan pendekatan kuantitatif. Subjek penelitian ini yaitu 67 Mahasiswa aktif Pendidikan Matematika UIN Sunan Kalijaga semester genap tahun ajaran 2019/2020. Instrumen pengumpulan data yaitu angket kemandirian belajar dan database KHS (Kartu Hasil Studi). Analisis data menggunakan analisis statistik deskriptif dan analisis regresi linear sederhana. Hasil penelitian menunjukkan bahwa kemandirian belajar secara daring dapat dijadikan prediksi terhadap hasil belajar Mahasiswa Pendidikan Matematika UIN Sunan Kalijaga dan semakin tinggi kemandirian belajar mahasiswa, maka hasil belajar juga akan semakin tinggi. Hal tersebut membuktikan bahwa kemandirian belajar selama daring memiliki peran yang penting terhadap hasil belajar mahasiswa, sehingga mahasiswa dapat meningkatkan kemandirian belajarnya agar hasil belajarnya dapat meningkat.
\end{abstract}

Kata kunci: Kemandirian Belajar, Daring, Hasil Belajar Mahasiswa, Pendidikan Matematika

Copyright (c) 2021 Riza Nur Fadila, Tia Ainun Nadiroh, Ria Juliana, Primasari Zahrah Hafizhotu Zulfa, Ibrahim $\triangle$ Corresponding author: Riza Nur Fadila

Email Address: rizanfadila48@gmail.com (Jalan Laksda Adisucipto, Sleman, Daerah Istimewa Yogyakarta)

Received 11 January 2021, Accepted 07 March 2021, Published 09 April 2021

\section{PENDAHULUAN}

Akhir tahun 2019, dunia dikejutkan dengan terjadinya penyebaran corona virus disease (Covid19) yang pertama kali muncul di Wuhan, Cina (Putria, Maula, \& Uswatun, 2020). Covid-19 merupakan penyakit jenis baru dengan gejala gangguan pernapasan akut seperti sesak napas dan demam (Dewi, 2020). Covid-19 ini telah menyebar ke seluruh dunia, salah satunya di Indonesia. Covid-19 mulai menyerang Indonesia pada tanggal 2 maret 2020 (Handayani, Hadi, Burhan, \& Agustin, 2020). Penyebaran Covid-19 ini sangat cepat sehingga pemerintah Indonesia menetapkan status lockdown dibeberapa daerah untuk memutus mata rantai penyebaran Covid-19 (Handarini \& Wulandari, 2020). 
Akibatnya banyak sektor negara yang lumpuh, salah satunya yaitu sektor pendidikan.

Pembelajaran yang biasanya dilakukan secara tatap muka kini beralih ke pembelajaran daring (dalam jaringan) baik tingkat sekolah maupun perguruan tinggi guna untuk mencegah penyebaran Covid-19. Hal tersebut dilakukan berdasarkan surat edaran yang telah dikeluarkan oleh Menteri Pendidikan dan Kebudayaan Nomor 36962/MPK.A/HK/2020 mengenai pembelajaran secara daring untuk pencegahan dan penanganan Covid-19 (Argaheni, 2020). Pembelajaran daring adalah pelaksanaan pembelajaran antara pendidik dan peserta didik tanpa berkontak fisik dengan memanfaatkan jaringan internet (Loviana \& Baskara, 2020). Metode pembelajaran daring dibagi menjadi 2 jenis yaitu synchronous dan asynchronous. Pembelajaran synchronous yaitu interaksi antara pendidik dan peserta didik secara langsung dengan audio atau video conference melalui media belajar yang terhubung dengan jaringan (Budiyanto \& Pujiyono, 2014). Sedangkan pembelajaran asychronous adalah interaksi pembelajaran secara tidak langsung dengan pendistribusian bahan ajar oleh pendidik melalui media pembelajaran online sehingga peserta didik dapat mengakses kapan pun dan dimana pun (Divayana, Heryanda, \& Suyasa, 2020).

Pelaksanaan pembelajaran menggunakan metode synchronous dan asynchronous masih menimbulkan beberapa permasalahan. Dalam pembelajaran secara synchronous seperti menggunakan aplikasi zoom atau yang serupa terkadang terdapat kendala koneksi internet yang menyebabkan penyampaian materi kurang jelas dan pemahaman materi kurang mendalam (Pratiwi, 2020). Hal ini juga diungkapkan oleh Niken Bayu Argaheni (Argaheni, 2020) bahwa pembelajaran daring membuat mahasiswa kesulitan dalam memahami konsep pembelajaran. Hal ini dikarenakan terbatasnya penjelasan materi oleh dosen, terutama pada metode asynchronous, dimana mahasiswa mencari dan memahami sendiri materi tersebut. Kesulitan tersebut juga dirasakan oleh mahasiswa pendidikan matematika UIN Sunan Kalijaga selama pelaksanaan pembelajaran daring. Hal ini karena konsep pada mata kuliah yang diambil mahasiswa pendidikan matematika lebih abstrak terutama pada materi pembelajaran dengan kesukaran yang lebih tinggi yang menyebabkan mahasiswa pendidikan matematika kesulitan dalam memahami materi tersebut (Kusumaningrum \& Wijayanto, 2020). Hal tersebut yang menyebabkan mahasiswa di tuntut untuk lebih memiliki kemandirian belajar agar dapat mencapai tujuan pembelajaran daring. Hal ini sesuai dengan Direktorat Jenderal Guru dan Tenaga Pendidikan (Ditjen GTK) (Ditjen GTK Kemendikbud, 2016) yang mengemukakan bahwa pembelajaran daring menuntut pembelajar (dalam hal ini mahasiswa) untuk menciptakan dan membangun pengetahuannya secara mandiri atau adanya kemandirian belajar.

Kemandirian belajar adalah kegiatan belajar atas kemauan dari diri sendiri tanpa bergantung pada orang lain, dan memiliki kepercayaan diri dalam menyelesaikan permasalahan yang dihadapi, serta memiliki perilaku aktif terlibat dalam pembelajaran dan inisiatif (Handayani \& Hidayat, 2018). Kemandirian belajar juga dapat diartikan dengan kemampuan siswa untuk melakukan aktivitas belajar tanpa bergantung pada orang lain dalam mencapai tujuan pembelajaran yang meliputi penguasaan materi dengan baik dan pengaplikasian pengetahuannya dalam menyelesaikan berbagai masalah (Suhendri, 
2011). Dalam hal ini, mahasiswa yang menerapkan kemandirian belajar akan mengorganisasikan dirinya sedemikian rupa sehingga dapat mencapai tujuan belajar yang telah dirumuskan. Keberhasilan pencapaian tujuan pembelajaran ini dapat dilihat dari hasil belajar. Keberhasilan belajar mahasiswa dalam bidang akademik biasanya ditunjukkan oleh indeks prestasi (IP) yang dicapai (Hasanah, et al., 2019). Indeks prestasi merupakan hasil belajar dari kegiatan belajar di perguruan tinggi yang bersifat kognitif dan biasanya ditentukan melalui pengukuran dan penilaian (Hadi, 2012). Oleh karena itu, kemandirian belajar memiliki peran penting dalam keberhasilan pencapaian tujuan pembelajaran yang dapat dilihat pada hasil belajar (Hidayat, Rohaya, Nadine, \& Ramadhan, 2020).

Penelitian sebelumnya yang dilakukan oleh Laila Fitriana (Fitriana, 2011) diperoleh bahwa kemandirian yang dimiliki siswa mempengaruhi prestasi belajarnya, dimana peserta didik yang memiliki kemandirian belajar tinggi, prestasi belajarnya lebih baik daripada peserta didik dengan kemandirian belajar yang sedang dan rendah. Peserta didik yang digunakan sebagai subjek penelitian adalah siswa SMP dan menyoroti materi matematika bangun ruang sisi datar. Penelitian ini perlu dikembangkan terhadap mahasiswa pada materi matematika untuk menguji apakah kemandirian belajar juga berpengaruh terhadap prestasi belajar mahasiswa salah satunya mahasiswa pendidikan matematika. Pada penelitian yang dilakukan oleh Siti Suminarti Fasikhah dan Siti Fatimah (Fasikhah \& Fatimah, 2013) menunjukkan bahwa adanya pengaruh pelatihan self-regulated learning (kemandirian belajar) terhadap peningkatan prestasi akademik (IP) mahasiswa. Dalam hal ini, peningkatan prestasi akademik (IP) mahasiswa dipengaruhi oleh kemandirian belajar, dimana semakin tinggi kemandirian belajar, maka prestasi belajar akan meningkat. Subjek penelitian tersebut yaitu mahasiswa Fakultas Psikologi UMM dan dilakukan saat perkuliahan tatap muka berlangsung (luar jaringan). Oleh karena itu, perlu adanya penelitian mengenai pengaruh kemandirian belajar terhadap prestasi akademik (IP) mahasiswa yang melakukan perkuliahan secara daring (dalam jaringan).

Berdasarkan pemaparan teori dan pendapat diatas, peneliti akan melakukan penelitian dengan judul "Kemandirian Belajar Secara Daring Sebagai Prediktor Hasil Belajar Mahasiswa Pendidikan Matematika UIN Sunan Kalijaga". Tujuan dari penelitian ini yaitu untuk mengetahui prediksi hasil belajar mahasiswa dari kemandirian belajar selama pembelajaran daring dan korelasi antara kemandirian belajar dengan hasil belajar selama pembelajaran daring. Penelitian ini akan meneliti prediksi hasil belajar dari kemandirian belajar secara daring Mahasiswa UIN Sunan Kalijaga dan seberapa besar pengaruh kemandirian belajar tersebut terhadap hasil belajar mahasiswa. Dengan mengetahui bahwa kemandirian belajar dapat menjadi prediktor hasil belajar dan mengetahui besarnya pengaruh kemandirian belajar terhadap hasil belajar selama pembelajaran daring, maka Mahasiswa Pendidikan Matematika dapat meningkatkan hasil belajar dengan cara meningkatkan kemandirian belajarnya. Selain itu, penelitian ini dapat menjadi pertimbangan dosen dalam meningkatkan kemandirian belajar mahasiswa agar hasil belajar selama pembelajaran daring meningkat. 


\section{METODE}

\section{Jenis dan Lokasi Penelitian}

Penelitian ini termasuk penelitian survey dengan pendekatan kuantitatif. Dalam penelitian ini terdapat 2 variabel yang diamati yaitu kemandirian belajar sebagai variabel bebas/variabel independen dan hasil belajar sebagai variabel terikat/variabel dependen. Penelitian ini dilaksanakan pada Program Studi Pendidikan Matematika Fakultas Ilmu Tarbiyah dan Keguruan Universitas Islam Negeri Sunan Kalijaga Yogyakarta yang berada di Jl. Laksda Adisucipto, Depok, Sleman, Daerah Istimewa Yogyakarta.

\section{Subjek Penelitian}

Dalam penelitian ini, yang menjadi populasi adalah seluruh mahasiswa aktif Program Studi Pendidikan Matematika Fakultas Ilmu Tarbiyah dan Keguruan Universitas Islam Negeri Sunan Kalijaga Yogyakarta angkatan 2017 sampai dengan angkatan 2019. Pengambilan sampel dalam penelitian ini menggunakan teknik simple random sampling. Teknik simple random sampling merupakan pengambilan anggota sampel dengan memberikan kesempatan yang sama kepada anggota populasi untuk menjadi sampel (Arieska \& Herdiani, 2018). Dari hasil penyebaran angket, diperoleh 67 Mahasiswa yang telah mengisi data tersebut, sehingga subjek penelitian ini sebanyak 67 Mahasiswa.

\section{Instrument dan Teknik Pengumpulan Data}

Instrumen pengumpulan data adalah alat ukur yang digunakan peneliti untuk mendapatkan informasi mengenai variabel yang akan diteliti (Nasution, 2016). Instrumen yang digunakan dalam penelitian ini adalah angket kemandirian belajar dan database KHS (Kartu Hasil Studi) Mahasiswa Pendidikan Matematika semester genap tahun ajaran 2019/2020. Database KHS yang berisi nilai IP (Indeks Prestasi) Mahasiswa digunakan sebagai data hasil belajar secara daring sedangkan angket kemandirian belajar digunakan sebagai data kemandirian belajar. Angket kemandirian belajar yang digunakan dalam penelitian ini berupa google form yang kemudian diisi oleh mahasiswa sesuai situasi dan keadaan pembelajaran secara daring. Angket ini diadopsi dari skripsi Sri Septiyaningsih (Septiyaningsih, 2017) yang telah valid dengan nilai reliabilitas sebesar 0.865 dengan kategori reliabilitas yang sangat tinggi. Uji validitas yang digunakan dalam angket ini adalah korelasi Product Moment, sedangkan uji reliabilitas dilakukan menggunakan rumus Cronbach's Alpha. Skala yang digunakan dalam angket ini yaitu skala likert yang terdiri dari 4 alternatif jawaban yaitu Selalu (SL), Sering (S), Jarang (J), Tidak Pernah (TP). Pada pernyataan positif, alternatif jawaban Selalu (SL) memiliki skor 4, Sering (S) memiliki skor 3, Jarang (J) memiliki skor 2, Tidak Pernah (TP) memiliki skor 1, sedangkan untuk pernyataan negatif, alternatif jawaban Selalu (SL) memiliki skor 1, Sering (S) memiliki skor 2, Jarang (J) memiliki skor 3, Tidak Pernah (TP) memiliki skor 4. Angket terdiri dari 16 pernyataan dari 6 indikator dengan kisi-kisi seperti pada tabel berikut : 
Tabel 1. Kisi - Kisi Instrumen Kemandirian Belajar

\begin{tabular}{|l|l|l|}
\hline Indikator & No. Butir & Jumlah \\
\hline Tidak Bergantung pada orang lain & $1,2^{*}, 3$ & 3 \\
\hline Memiliki sifat tanggung jawab & 4,5 & 2 \\
\hline Percaya diri & 6,7 & 2 \\
\hline Disiplin & $8,9^{*}, 10$ & 3 \\
\hline Berperilaku berdasarkan inisiatif sendiri & $11,12,13$ & 3 \\
\hline Melakukan kontrol diri & $14,15,16$ & 3 \\
\hline Jumlah & & 16 \\
\hline
\end{tabular}

*) pernyataan negatif

Teknik pengumpulan data dalam penelitian ini yaitu penyebaran angket kemandirian belajar dan kajian dokumentasi. Penyebaran angket kemandirian belajar ini dilakukan dengan memberikan link google form melalui whatsApp group kepada Mahasiswa Pendidikan Matematika. Penyebaran angket tersebut untuk mendapatkan data kemandirian belajar mahasiswa, sedangkan kajian dokumentasi digunakan untuk mendapatkan data hasil belajar mahasiswa. Dokumentasi adalah segala sesuatu benda yang memberikan informasi absah dan penting baik berupa tulisan, barang maupun gambar (Pebrianti, 2016). Teknik kajian dokumentasi pada penelitian ini berupa database Indeks Prestasi Mahasiswa Pendidikan Matematika semester genap tahun ajaran 2019/2020.

\section{Analisis Data}

Hasil angket kemandirian belajar secara daring dan data IP (Indeks Prestasi) mahasiswa yang telah dikumpulkan, kemudian diolah dan dianalisis dengan software Microsoft Excell 2010 dan SPSS versi 26 untuk mencari statistik deskriptif dan uji hipotesis menggunakan analisis regresi linear sederhana. Statistik deskriptif merupakan statistik yang menggambarkan atau menganalisis hasil penelitian tanpa membuat generalisasi (Sugiyono, 2012). Deskripsi data tersebut meliputi banyaknya data, nilai rerata (mean), standar deviasi, nilai minimum, nilai maksimum, varians, dan skor ideal.

Uji hipotesis dalam penelitian ini dianalisis menggunakan teknik analisis regresi linear sederhana. Regresi linear sederhana adalah metode statistik yang digunakan untuk memprediksi nilai Y (variabel terikat) dari nilai X (satu variabel bebas) yang diberikan (Hijriani, Muludi, \& Andini, 2016). Persamaan model regresi linear sederhana yaitu (Hijriani, Muludi, \& Andini, 2016) :

$$
\mathrm{Y}=\mathrm{a}+\mathrm{bX}
$$

Dalam penelitian ini, analisis regresi linear sederhana digunakan untuk memprediksi nilai hasil belajar mahasiswa berdasarkan nilai kemandirian belajar secara daring. Ada uji asumsi klasik yang harus dipenuhi agar model analisis regresi linear sederhana tersebut valid sebagai alat penduga yaitu uji normalitas, uji linearitas, dan uji heteroskedastisitas. Jika data tersebut berdistribusi normal, linear, dan tidak terjadi gejala heteroskedastisitas, maka dilanjutkan dengan analisis regresi linear sederhana. Tingkat signifikansi $(\alpha)$ yang digunakan dalam penelitian ini yaitu 0.05 .

Uji normalitas dilakukan untuk mengetahui apakah nilai residual dari variabel kemandirian belajar dan hasil belajar tersebut berdistribusi normal. Uji normalitas dalam penelitian ini menggunakan uji Kolmogorov Smirnov di SPSS 26. Data akan berdistribusi normal apabila nilai asym. Sig. (2-tailed) 
unstandardized residual >0.05. Uji linearitas dilakukan untuk mengetahui ada atau tidaknya hubungan yang linear secara signifikan antara dua variabel yang diteliti tersebut (Qomusuddin, 2019). Kriteria pengambilan keputusan dalam uji linearitas ini dengan membandingkan nilai signifikansi (sig.) dengan tingkat signifikansi $(\alpha)$ 0.05. Jika nilai sig. deviation from linearity $>0.05$, maka terdapat hubungan yang linear secara signifikan antara kemandirian belajar dengan hasil belajar. Uji heteroskedastisitas dilakukan untuk mengetahui apakah terjadi ketidaksamaan varians residual untuk semua pengamatan dalam model regresi (Wardana, 2020). Dalam uji heteroskedastisitas ini, peneliti menggunakan uji Glejser yaitu meregresikan variabel bebas dengan nilai mutlak residual (Abs_Res). Jika nilai sig. > 0.05, maka tidak terjadi gejala heteroskedastisitas dalam model regresi. Tahap selanjutnya yaitu uji analisis regresi linear sederhana. Hasil uji regresi tersebut akan menghasilkan tabel ANOVA, Coefficients, dan model summary. Kriteria pengambilan keputusan dari tabel ANOVA yaitu apabila nilai signifikansi (sig.) $<0.05$, maka model regresi tersebut dapat digunakan untuk memprediksi hasil belajar, sedangkan pada tabel Coefficients, jika nilai signifikansi $<0.05$, maka terdapat pengaruh antara kemandirian belajar (variabel X) terhadap hasil belajar (variabel Y). Analisis pada tabel uji regresi data model summary dengan cara membandingkan nilai $\mathrm{R}$ dengan tingkast signifikansi. Kriteria pengujiannya yaitu apabila nilai $\mathrm{R}>0.05$, maka hubungan antara kemandirian belajar secara daring dengan hasil belajar adalah kuat.

\section{HASIL DAN DISKUSI}

Dalam penelitian ini, data kemandirian belajar secara daring dapat dilihat dari hasil angket, sedangkan hasil belajar dapat dilihat dari IP (indeks prestasi) 67 Mahasiswa Pendidikan Matematika UIN Sunan Kalijaga. Data tersebut diolah dengan analisis statistik deskriptif dengan aplikasi SPSS versi 26 untuk mengetahui banyaknya data, nilai rerata (mean), standar deviasi, nilai minimum, nilai maksimum, varians, dan skor ideal. Berikut ini hasil analisis statisik deskriptif data kemandirian belajar dan hasil belajar yang disajikan dalam tabel 2 .

Tabel 2. Hasil Analisis Statistik Deskriptif Kemandirian Belajar dan Hasil belajar

\begin{tabular}{|c|c|c|c|c|c|c|c|}
\hline Variabel & $\mathrm{N}$ & Rerata & $\begin{array}{c}\text { Standar } \\
\text { Deviasi }\end{array}$ & Minimum & Maksimum & Variance & $\begin{array}{c}\text { Skor } \\
\text { Ideal }\end{array}$ \\
\hline Kemandirian Belajar & 67 & 48.493 & 5.7561 & 26.0 & 63.0 & 33.133 & 64 \\
\hline Hasil Belajar & 67 & 3.5646 & 0.14716 & 3.21 & 3.97 & 0.022 & 4.00 \\
\hline
\end{tabular}

Berdasarkan output analisis deskriptif variabel kemandirian belajar diatas, diketahui bahwa banyaknya data sebanyak 67, nilai rerata (mean) sebesar 48.49, nilai minimum sebesar 26, nilai maksimum sebesar 63, standar deviasi sebesar 5.756, varians sebesar 33.133, dan skor ideal sebesar 64 . Pada variabel hasil belajar, didapatkan banyaknya data sebesar 67, nilai rerata (mean) sebesar 3.5646, standar deviasi sebesar 0.14716, nilai minimum sebesar 3.21, nilai maksimum sebesar 3.97, varians sebesar 0.022 , dan skor ideal sebesar 4.00 . 
Tahap selanjutnya yaitu uji hipotesis untuk mengetahui seberapa besar variabel kemandirian belajar secara daring sebagai prediktor hasil belajar. Uji hipotesis dalam penelitian ini dilakukan menggunakan analisis regresi linear sederhana. Sebelum dilakukan analisis regresi linear sederhana, perlu dilakukan uji asumsi klasik sebagai syarat agar model analisis regresi linear sederhana tersebut valid sebagai alat penduga. Uji asumsi klasik dalam penelitian ini yaitu uji normalitas, uji linearitas, dan uji heteroskedastisitas.

Pertama, uji normalitas dari data yang diperoleh untuk mengetahui apakah nilai residual dari variabel kemandirian belajar dan hasil belajar mahasiswa berdistribusi normal. Berikut ini merupakan hasil uji normalitas data variabel kemandirian belajar dan hasil belajar menggunakan One-Sample Kolmogorov-Smirnov Test yang disajikan pada tabel 3.

Tabel 3. Uji Normalitas Data

\begin{tabular}{|c|c|}
\hline & Unstandardized Residual \\
\hline $\mathrm{N}$ & 67 \\
\hline Asymp. Sig. (2-tailed) & $.200^{\mathrm{c}, \mathrm{d}}$ \\
\hline
\end{tabular}

Pada hasil uji One-Sample Kolmogorov Smirnov diatas, didapatkan nilai asym. Sig. (2-tailed) unstandardized residual sebesar 0.200. Nilai signifikansi $0.200>0.05$, maka dapat disimpulkan bahwa data tersebut berdistribusi normal.

Uji asumsi klasik selanjutnya yaitu uji linearitas. Berikut hasil uji linearitas data kemandirian belajar dan hasil belajar yang disajikan dalam tabel 4 .

Tabel 4. Uji Linearitas data

\begin{tabular}{|l|l|c|c|}
\hline \multicolumn{2}{|l|}{} & Sig. \\
\hline Hasil \begin{tabular}{l|l|} 
Belajar*Kemandirian \\
Belajar
\end{tabular} & Between Groups & (Combined) & 0.341 \\
\cline { 3 - 4 } & & Linearity & 0.32 \\
\cline { 3 - 4 } & $\begin{array}{l}\text { Deviation from } \\
\text { Linearity }\end{array}$ & 0.519 \\
\hline
\end{tabular}

Berdasarkan output diatas, nilai sig. deviation from linearity sebesar 0.519. Nilai signifikansi $=$ $0.519>0.05$, maka dapat disimpulkan bahwa terdapat hubungan linear secara signifikan antara variabel kemandirian belajar (X) dengan variabel hasil belajar (Y). Uji asumsi klasik selanjutnya yaitu uji heteroskedastisitas. Uji ini dilakukan dengan menggunakan uji Glejser. Berikut hasil uji Glejser untuk data penelitian ini yang disajikan dalam tabel 5 .

Tabel 5. Uji Heteroskedastisitas

\begin{tabular}{|c|c|c|c|}
\hline Model & & $\mathrm{t}$ & Sig. \\
\hline \multirow{2}{*}{1} & (Constant) & 2.310 & 0.024 \\
\cline { 2 - 4 } & Kemandirian Belajar & -1.146 & 0.256 \\
\hline
\end{tabular}

Berdasarkan output diatas, didapatkan nilai signifikansi (sig.) variabel kemandirian belajar sebesar 0.256 , dimana $0.256>0.05$, maka tidak terjadi heteroskedastisitas dalam model regresi, sehingga memenuhi uji asumsi klasik. 
Dari pemaparan tersebut, dapat disimpulkan bahwa model regresi linear sederhana dari data tersebut valid sebagai alat ukur karena telah memenuhi ketiga uji asumsi klasik yaitu data penelitian ini berdistribusi normal, adanya hubungan linear secara signifikan antara variabel kemandirian belajar dengan variabel hasil belajar, dan tidak terjadi heteroskedastisitas dalam model regresi. Oleh karena itu, uji hipotesis dapat dilakukan dengan analisis regresi linear sederhana.

Analisis regresi linear sederhana dalam penelitian ini menggunakan aplikasi SPSS versi 26. Hasil analisis tersebut disajikan dalam tabel 6,7 , dan 8 , sebagai berikut ini:

Tabel 6. Uji Regresi Data (ANOVA)

\begin{tabular}{|c|c|c|c|c|}
\hline Model & & Df & F & Sig. \\
\hline \multirow{3}{*}{1} & Regression & 1 & 4.990 & 0.029 \\
\cline { 2 - 5 } & Residual & 65 & & \\
\cline { 2 - 5 } & Total & 66 & & \\
\hline
\end{tabular}

Berdasarkan tabel uji regresi data ANOVA, didapatkan bahwa F hitung sebesar 4.990 dengan nilai signifikansi (sig.) $0.029<0.05$, maka model regresi tersebut dapat digunakan untuk memprediksi hasil belajar. Analisis regresi selanjutnya yaitu uji untuk mengetahui pengaruh antara kemandirian belajar dan hasil belajar dengan melihat hasil output SPSS coefficients. Hasil uji regresi data coefficients tersebut disajikan dalam tabel 7.

Tabel 7. Uji Regresi Data (Coefficients)

\begin{tabular}{|c|c|c|c|c|}
\hline \multirow{2}{*}{ Model } & & \multicolumn{2}{|c|}{ Unstandardized Coefficients } & \multirow{2}{*}{ Sig. } \\
\cline { 3 - 4 } & & B & Std. Error & 0.000 \\
\hline \multirow{2}{*}{1} & (Constant) & 3.234 & 0.149 & 0.000 \\
\cline { 2 - 4 } & Kemandirian Belajar & 0.007 & 0.003 & 0.029 \\
\hline
\end{tabular}

Berdasarkan tabel uji regresi data coefficients diatas, diketahui nilai signifikansi (sig.) sebesar 0.029. Nilai signifikansi $0.029<0.05$, maka terdapat pengaruh antara kemandirian belajar (variabel X) terhadap hasil belajar (variabel Y). Dari tabel uji regresi linear sederhana tersebut, dapat dibuat model persamaan regresi antara kemandirian belajar dengan hasil belajar. Persamaan tersebut adalah $\mathrm{Y}=3.234$ + 0.007X, dengan $\mathrm{Y}$ adalah variabel hasil belajar, sedangkan $\mathrm{X}$ adalah variabel kemandirian belajar. Nilai a (nilai unstandardized coefficients) dalam persamaan regresi tersebut yaitu 3.234. Dalam hal ini, jika tidak ada kemandirian belajar secara daring (variabel X), maka nilai konsisten hasil belajar (variabel Y) sebesar 3.234. Nilai b dalam persamaan regresi tersebut sebesar 0.007. Nilai b ini menunjukan bahwa setiap penambahan 1 nilai kemandirian belajar (variabel X), maka hasil belajar (variabel Y) meningkat sebesar 0.007. Hasil uji regresi data selanjutnya yaitu model summary yang disajikan dalam tabel 8 .

Tabel 8. Uji Regresi data Model Summary

\begin{tabular}{|c|c|c|c|c|}
\hline Model & R & R Square & Adjusted R Square & Std.Error of the Estimate \\
\hline 1 & $.267^{\mathrm{a}}$ & 0.071 & 0.057 & 0.14290 \\
\hline
\end{tabular}

a. Predictors: (Constant), Kemandirian Belajar 
Tabel uji regresi data model summary menunjukakan bahwa nilai $\mathrm{R}$ sebesar 0.267 , dimana nilai $\mathrm{R}=0.267>0.05$, maka hubungan antara kemandirian belajar secara daring dengan hasil belajar adalah kuat. Nilai koefisien determinasi (R Square) sebesar 0.071 yang berarti pengaruh efektif kemandirian belajar terhadap hasil belajar sebesar 7.1\%, sedangkan 92.9\% dipengaruhi oleh faktor lain yang tidak diteliti. Tingkat ketepatan prediksi regresi penelitian ini sebesar 0.14290. Hal tersebut dapat dilihat dari nilai std error of the estimate sebesar 0.14290 pada tabel diatas.

Berdasarkan pemaparan diatas, menunjukkan bahwa kemandirian belajar dapat dijadikan prediktor hasil belajar Mahasiswa Pendidikan Matematika UIN Sunan Kalijaga selama pembelajaran daring. Hasil tersebut juga menunjukkan bahwa ada pengaruh yang positif antara kemandirian belajar secara daring terhadap hasil belajar yang dapat diartikan bahwa jika kemandirian belajar mahasiswa tinggi, maka hasil belajarnya juga akan tinggi. Hal tersebut juga berlaku sebaliknya, jika kemandirian belajar yang dimiliki mahasiswa rendah, maka hasil belajarnya pun akan rendah. Dengan kata lain, kemandirian belajar dalam penelitian ini yang meliputi rasa bertanggungjawab, disiplin, tidak bergantung pada orang lain, berperilaku berdasarkan inisiatif sendiri, percaya diri, dan melakukan kontrol diri merupakan hal yang perlu dimiliki mahasiswa agar memperoleh hasil belajar yang tinggi. Hal ini karena mahasiswa yang memiliki kemandirian belajar tersebut, akan mengontrol dirinya dalam membuat keputusan belajar sendiri tanpa bergantung pada orang lain, serta bertanggungjawab terhadap keputusannya untuk mendapatkan hasil belajar yang tinggi. Dalam penelitian ini, besar pengaruh kemandirian belajar mahasiswa selama pembelajaran daring terhadap hasil belajar sebesar $7.1 \%$, sedangkan $92.9 \%$ dipengaruhi oleh faktor lain yang tidak diteliti. Faktor lain dalam hal ini dapat berasal dari dalam diri mahasiswa seperti konsentrasi belajar, motivasi belajar, intelegensi, dan faktor yang berasal dari luar diri mahasiswa seperti metode pembelajaran dan kebijakan penilaian (Dimyati \& Mudjiono, 2013).

Hasil penelitian ini diperkuat dengan hasil penelitian yang dilakukan Misdalina (2017) yang mengemukakan bahwa kemandirian belajar memiliki pengaruh terhadap hasil belajar mahasiswa pendidikan matematika dengan kontribusi kemandirian belajar terhadap hasil belajar mahasiswa sebesar 15\%. Dalam penelitian yang dilakukan Rita Ningsih (2016) mengungkapkan bahwa kemandirian belajar memiliki pengaruh positif yang signifikan terhadap prestasi belajar matematika, dimana semakin tinggi kemandirian belajar, maka prestasi belajar matematika akan tinggi. Selain itu, pada penelitian yang dilakukan Suhendri (2011) mengungkapkan bahwa adanya pengaruh positif antara kemandirian belajar terhadap hasil belajar. Dalam hal ini, kemandirian belajar memiliki peran penting terhadap hasil belajar mahasiswa terutama selama pembelajaran daring karena mahasiswa dituntut untuk mengikut pembelajaran dengan baik walaupun tanpa proses tatap muka secara langsung dengan dosen (Badjeber, 2020). Dengan kata lain, mahasiswa perlu memiliki kemandirian belajar agar proses pembelajaran daring berjalan dengan baik sehingga mahasiswa dapat mencapai tujuan pembelajaran yang dapat dilihat pada hasil belajar (IP). 


\section{KESIMPULAN}

Kemandirian belajar secara daring dapat dijadikan prediksi terhadap hasil belajar Mahasiswa Pendidikan Matematika UIN Sunan Kalijaga. Dalam hal ini, kemandirian belajar secara daring memiliki pengaruh positif terhadap hasil belajar mahasiswa dan kedua variabel memiliki hubungan yang kuat. Jika kemandirian belajar mahasiswa dalam pembelajaran daring semakin tinggi, maka hasil belajar juga akan semakin tinggi. Setiap penambahan 1 nilai kemandirian belajar (variabel $\mathrm{X}$ ), maka hasil belajar (variabel Y) meningkat sebesar 0.007. Pengaruh kemandirian belajar secara daring terhadap hasil belajar tersebut sebesar $7.1 \%$, sedangkan $92.9 \%$ dipengaruhi oleh faktor lain yang tidak diteliti.

Dalam pembelajaran secara daring, masih ada beberapa faktor yang mempengaruhi hasil belajar mahasiswa. Hal ini dapat dilihat dari besarnya pengaruh faktor lain terhadap hasil belajar mahasiswa dari penelitian ini yaitu 92.9\%, yang mengindikasikan bahwa masih ada faktor lain yang mempengaruhi hasil belajar mahasiswa. Oleh karena itu, para peneliti dapat mengembangkan penelitian ini menggunakan variable bebas yang lainnya. Selain itu, para Peneliti dapat mengembangkan penelitian ini dengan menggunakan sampel yang lebih luas agar generalisasi hasil penelitian semakin meningkat.

\section{UCAPAN TERIMA KASIH}

Ucapan terima kasih diberikan kepada Bapak Dr. Ibrahim, S.Pd., M.Pd. selaku dosen pembimbing yang telah memberikan bimbingan dan pengarahan dalam proses pembuatan artikel ini, serta izin untuk melakukan penelitian terhadap Mahasiswa Pendidikan Matematika UIN Sunan Kalijaga selaku Ketua Program Studi Pendidikan Matematika UIN Sunan Kalijaga. Kemudian ucapan terima kasih ditunjukkan kepada orang tua dan para sahabat yang telah mendukung dan memberi semangat.

\section{REFERENSI}

Argaheni, N. B. (2020). Sistematik Review: Dampak Perkuliahan Daring Saat Pandemi Covid-19 Terhadap Mahasiswa Indonesia. Placentum Jurnal Ilmiah Kesehatan Dan Aplikasinya, 8 (2), 99108. Solo. DOI : http://doi.org/10.20961/placentum.v812.43008

Arieska, P. K., \& Herdiani, N. (2018). Pemilihan Teknik Sampling Berdasarkan Perhitungan Efisiensi Relatif. Statistika, 6(2), 166-171. Semarang. URL : https://jurnal.unimus.ac.id/index.php/statistik/article/view/4322/4001

Badjeber, R. (2020). Kemandirian Belajar Mahasiswa Tadris Matematika FTIK IAIN Palu Selama Masa Pembelajaran Daring. Koordinat Jurnal Pembelajaran Matematika dan Sains, 1(1), 1-9. URL : https://.jurnalkoordinat.org/index.php/koordinat/article/view/1

Budiyanto, A., \& Pujiyono, W. (2014). Sistem Broadcast Proses Belajar Mengajar dengan Synchronous dan Asynchronous. Jurnal Sarjana Teknik Informatika, 2(1), 749-761. URL: http://journal.uad.ac.id/index.php/JSTIF/article/view/2605

Dewi, W. A. (2020). Dampak Covid-19 Terhadap Implementasi Pembelajaran Daring di Sekolah Dasar. Edukatif : Jurnal Ilmu Pendidikan, 2(1), 55-61. DOI: https://doi.org/10.31004/edukatif.v2i1.89 
Dimyati, \& Mudjiono. (2013). Belajar dan Pembelajaran. Jakarta: PT. Rineka Cipta.

Ditjen GTK Kemendikbud. (2016). Petunjuk Teknis Program Peningkatan Guru Pembelajar Moda dalam Jaringan (Daring). Jakarta.

Divayana, G. H., Heryanda, K. K., \& Suyasa, P. A. (2020). Pemberdayaan Pembelajaran Synchronous Dan Asynchronous Berbasis Nilai-Nilai Aneka Dalam Upaya Peningkatan Karakter Positif Siswa. Proceeding Senadimas Undiksha ke-5, Septemnber, 307-316. URL : https://lppm.undiksha.ac.id/senadimas2020/assets/ProsidingSenadimas2020/file/42.pdf

Fasikhah, S. S., \& Fatimah, S. (2013). Self Regulated Learning (SLR) Dalam Meningkatkan Prestasi Akademik Pada Mahasiswa. Jurnal Ilmiah Psikologi Terapan, 1(1), 145-155. URL : http://ejournal.umm.ac.id/index.php/jipt/article/viewFile/1364/1459

Fitriana, L. (2011). Pengaruh Model Pembelajaran Cooperative Tipe Group Investigation (GI) dan STAD Terhadap Prestasi Belajar Matematika Ditinjau Dari Kemandirian Belajar Siswa. PROSIDING Seminar Nasional Matematika dan Pendidikan Matematika, 319-336. URL : http://eprints.uny.ac.id/id/eprint/7384

Handarini, O. I., \& Wulandari, S. S. (2020). Pembelajaran Daring Sebagai Upaya Study From Home (SFH) Selama Pandemi Covid 19. Jurnal Pendidikan Administrasi Perkantoran (JPAP), 8(3), 496-503. URL : https://journal.unesa.ac.id/index.php/jpap/article/view/8503

Handayani, D., Hadi, D. R., Burhan, E., \& Agustin, H. (2020). Penyakit Virus Corona 2019. Jurnal Respirologi Indonesia. 40(2), April, 119-129. URL : https://jurnalrespirologi.org/index.php/jri/article/view/101/110

Handayani, N., \& Hidayat, F. (2018). Hubungan Kemandirian Terhadap Hasil Belajar Siswa Mata Pelajaran Matematika di Kelas X SMK Kota Cimahi. Journal On Education, 1(2), Februari,1-8. URL : https://jonedu.org/index.php/joe/article/view/16

Hasanah, H., Fadiyah, L., Muzayyanah, T., Hasanah, R., Lindasari, Utami, D. L., et al. (2019). Analisis Hasil Belajar Dengan Nilai Indeks Prestasi Kumulatif (IPK) Mahasiswa STAI At-taqwa Bondowoso. Jurnal Pendidikan dan Keislaman. 5(2), 29-39. DOI: https://doi.org/10.230303/staiattaqwa.v5i2.42

Hidayat, D. R., Rohaya, A., Nadine, F., \& Ramadhan, H. (2020). Kemandirian Belajar Peserta Didik Dalam Pembelajaran Daring Pada Masa Pandemi Covid-19. Perspektif Ilmu Pendidikan, 34(2), Oktober, 147-154. DOI: https://doi.org/10.21009/PIP.342.9

Hijriani, A., Muludi, K., \& Andini, E. A. (2016). Implementasi Metode Regresi Linier Sederhana Pada Penyajian Hasil Prediksi Pemakaian Air Bersih PDAM Way Rilau Kota Bandar Lampung Dengan Sistem Informasi Geografis. Jurnal Informatika Mulawarman, 11(2), September, 37. DOI: http://dx.doi.org/10.30872/jim.v11i2.212

Kusumaningrum, B., \& Wijayanto, Z. (2020). Apakah Pembelajaran Matematika Secara Daring Efektif? (Studi Kasus pada Pembelajaran Selama Masa Pandemi Covid-19. KREANO Jurnal Matematika Kreatif-inovatif, 11(2), 136-142. DOI: https://doi.org/10.15294/kreanno.v11i2.25029 
Loviana, S., \& Baskara, W. N. (2020). Dampak Pandemi Covid-19 Pada Kesiapan Pembelajaran Tadris Matematika IAIN Metro Lampung. Epsilon Jurnal Pendidikan Matematika STKIP-PGRI, 2(1), 61-70. Bandar Lampung. URL: http://jurnal.stkippgribl.ac.id/index.php/epsilon/issue/view/45 Misdalina, Ningsih, Y. L., \& Marhamah. (2017). Pengaruh Kemandirian Belajar Terhadap Hasil Belajar Mahasiswa. PROSIDING : Seminar Nasional Pendidikan PGRI, 858-861.

Nasution, H. F. (2016). Instrumen Penelitian dan Urgensinya dalam Penelitian Kuantitatif. Al-Masharif : Jurnal Ilmu Ekonomi dan Keislaman, 4(1),59-75. Padang .DOI: https://doi.org/10.24952/masharif.v4i1

Ningsih, R. (2016). Pengaruh Kemandirian Belajar dan Perhatian Orang Tua Terhadap Prestasi Belajar Matematika. Jurnal Formatif, 6(1), 73-84. Jakarta.DOI: http://dx.doi.org/10.30998/formatif.v6i1.754

Pebrianti, Y. (2016). Kajian Penyusunan Dokumen Sistem (Panduan, Prosedur, dan Formulir) Guna Mendukung Manajemen Mutu Perpustakaan Study Preparation Of Sistem Document (Guidance, Procedurs, and Form) To Support Library Quality Management). Jurnal Pari, 2(2), 78-91. Bogor.URL: http://ejournal-balitbang.kkp.go.id/index.php/JP/article/view/3252

Pratiwi, E. W. (2020). Dampak Covid-19 Terhadap Kegiatan Pembelajaran Online Di Sebuah Perguruan Tinggi Kristen Di Indonesia. Perspektif Ilmu Pendidikan, 34(1), 1-8.Salatiga. DOI: https://doi.org/10.21009/PIP.341.1

Putria, H., Maula, L. H., \& Uswatun, D. A. (2020). Analisis Proses Pembelajaran Dalam Jaringan (Daring) Masa Pandemi Covid-19 Pada Dalam Jaringan (Daring) Masa Pandemi Covid-19 Pada Guru Sekolah Dasar. Jurnal Basicedu, 4(4), 861-872.Jawa barat .DOI: https://doi.org/10.31004/basicedu.v4i4.460

Qomusuddin, I. F. (2019). Statistika Pendidikan (Lengkap dengan Aplikasi IBM SPSS Statistika 20.0). Sleman: Deepublish.

Septiyaningsih, S. (2017). Pengaruh Aktivitas Belajar dan Kemandirian Belajar Terhadap Prestasi Belajar Mahasiswa Pendidikan Ekonomi Angkatan 2013 . Universitas Negeri Yogyakarta, 41-46.

Sugiyono. (2012). Statistika Untuk Penelitian. Bandung: Alfabeta.

Suhendri, H. (2011). Pengaruh Kecerdasan Matematis-Logis dan Kemandirian Belajar Terhadap Hasil Belajar Matematika. Formatif, 1(1), 29-39.Jakarta selatan .DOI: http://dx.doi.org/10.30998/formatif.v1i1.61

Wardana. (2020). Pengantar Aplikasi SPSS Versi 20. Yogyakarta: LPPM Universitas Muhammadiyah Buton Press. 